\title{
Social Representations of Art in Public Places: A Study of Everyday Explanations of the Statue of 'A Real Birmingham Family'
}

\author{
Peter J. Aspinall
}

check for updates

Citation: Aspinall, Peter J. 2021. Social Representations of Art in Public Places: A Study of Everyday Explanations of the Statue of 'A Real Birmingham Family'. Genealogy 5: 59. https://doi.org/10.3390/ genealogy5030059

Received: 5 May 2021

Accepted: 13 June 2021

Published: 22 June 2021

Publisher's Note: MDPI stays neutral with regard to jurisdictional claims in published maps and institutional affiliations.

Copyright: (C) 2021 by the author. Licensee MDPI, Basel, Switzerland. This article is an open access article distributed under the terms and conditions of the Creative Commons Attribution (CC BY) license (https:/ / creativecommons.org/licenses/by/ $4.0 /)$.
Centre for Health Services Studies, University of Kent, Canterbury CT2 7NF, UK; P.J.Aspinall@kent.ac.uk

\begin{abstract}
This article focuses on the social/cultural representations of the statue of A Real Birmingham Family cast in bronze and unveiled in Britain's second city in October 2014. It reveals a family comprising two local mixed-race sisters, both single mothers, and their sons, unanimously chosen from 372 families. Three of the four families shortlisted for the statue were 'mixed-race' families. The artwork came about through a partnership between the sculptress, Gillian Wearing, and the city's Ikon Gallery. A number of different lay representations of the artwork have been identified, notably, that it is a 'normal family with no fathers' and that it is not a 'typical family'. These are at variance with a representation based on an interpretation of the artwork and materials associated with its creation: that a nuclear family is one reality amongst many and that what constitutes a family should not be fixed. This representation destabilizes our notion of the family and redefines it as empirical, experiential, and first-hand, families being brought into recognition by those in the wider society who choose to nominate themselves as such. The work of Ian Hacking, Richard Jenkins, and others is drawn upon to contest the concept of 'normality'. Further, statistical data are presented that show that there is now a plurality of family types with no one type dominating or meriting the title of 'normal'. Finally, Wearing's statues of families in Trentino and Copenhagen comprise an evolving body of cross-national public art that provides further context and meaning for this representation.
\end{abstract}

Keywords: social/cultural representations; Birmingham; Gillian Wearing; Ikon Gallery; mixed race; normality; family types

\section{Introduction}

Tate Galleries (Tate.org) defines the term 'public art' as art that is in the public realm, regardless of whether it is situated on public or private property or whether it has been purchased with public or private money. It adds: 'Usually, but not always, public art is commissioned specifically for the site in which it is situated. Monuments, memorials, and civic statues and sculptures are the most established forms of public art, but public art can also be transitory, in the form of performances, dance, theatre, poetry, graffiti, posters and installations' (https:/ / www.tate.org.uk/art/art-terms/p/public-art, accessed on 1 May 2021). Public art may be used as a political tool and also as a form of civic protest. The murals painted by the Ulster Unionists in Northern Ireland provide an example from our recent past. More recently, the 'Black Lives Matter' movement has challenged the acceptability of one genre of public art in our towns and cities, civic statues and sculptures that celebrate Britain's colonial past.

The ongoing debate about statues of slave traders has exposed a range of views, from demands for their removal as they provide a public validation of inhuman acts, to those that argue that their presence in our townscapes provides a reminder of our history and is therefore of value in a teaching context. The response to these moral complexities includes the toppling and destruction of statues by protesters (notably, that of Edward Colston in Bristol, located high up on a pedestal, like much of this art), an action supported by historian David Olusoga (Olusoga 2020); the quiet removal of these statues; the suggestion by Simon 
Shama and others that such statues be consigned to museums; and the government's recent policy measures to protect them. Many of these statues have been in our cities for years (Edward Colston's statue was erected in 1895) and so represent public art created in a different era. 'Black Lives Matter' (BLM) has also acted as a catalyst for the creation of sculptures that celebrate our ethnic and cultural diversity. Examples include Marc Quinn's statue of BLM protester Jen Reid which temporarily occupied the plinth of the ejected Colston Statue and Péter Szalay's crouched and rainbow-coloured Statue of Liberty in Budapest.

However, not all new public art that celebrates our ethnic/racial diversity has grown out of the BLM protest movement. A less well-known lineage has focused on the family in all its diversity, including the now broad range of family types and the diverse ethnic/racial composition of families. The 'A Real Birmingham Family' project had its origins in 2011 and was located in the discourse on diversity in family forms, especially those that are not readily recognized or well known. It also focused on the quality of the relationship between members in these family forms and the relationships of the families to the city of Birmingham.

Thus, public art can invoke the past, present and future and how they intersect and the coming together of disciplines, ideas, and discourses, making it fertile ground for the study of social/cultural representations, that is, the way the lay public elaborates and circulates forms of knowledge that are important, relevant, and attention-grabbing for society as a whole (Lorenzi-Cioldi and Clémence 2010, p. 823; Aspinall 2015). The term social representation originated with Serge Muscovici (1961), in his study on the reception and circulation of psychoanalysis in France. He explained it as the collective elaboration 'of a social object by the community for the purpose of behaving and communicating' (Moscovici 1963). The theory takes as its starting point the plurality of meaning and therefore has the potential to offer substantial insight into shared realities. The concept of 'cultural representations', a sub-genre, has been developed by Stuart Hall within the discipline of cultural studies that originated in 1960s Britain. Hall describes such representations as 'an essential part of the process by which meaning is produced and exchanged between members of a culture' (Hall 1997). According to Hall, there is room in a culture and associated social practices for both ascribing meaning and constructing meaning, which in turn shapes human identity.

\section{Results}

\subsection{A Real Birmingham Family: How the Project Came about}

This article focuses on the social/cultural representations of the statue of $A$ Real Birmingham Family that was cast in bronze and unveiled in Britain's second city in October 2014. It reveals a family comprising two local mixed-race sisters, both single mothers, and their sons. The lineage for such artwork was the exclusive creation of the sculptress, Gillian Wearing, and, in the Birmingham context, came about through a partnership with the city's Ikon Gallery, who helped to coordinate the project, including the process of selecting the family.

That Gillian Wearing should have been the creative driver of this project is not surprising. She has had a long-standing interest in the meaning of the family and also strong associations with the city of Birmingham, where she was born. This was not the first time that Wearing had addressed the subject of the family in her sculptures. The project followed her 2008 sculptural work, A Typical Trentino Family, and, in turn, was followed by the bronze cast of A Real Danish Family in 2017. Her other notable work includes the 2018 statue of the suffragist Millicent Fawcett that stands in London's Parliament Square.

Gillian Wearing, awarded the OBE in 2011 and CBE in 2019, was born on 10 December 1963 in the city of Birmingham. She attended Dartmouth High School in Great Barr, Birmingham, then moved to Chelsea, London, to study art at the Chelsea School of Art (1985-87), where she attained a bachelor of technology degree in art and design in 1987. In 1990 she gained a Bachelor of Fine Arts (BFA) degree from Goldsmiths, University of London. She quickly established a reputation as an English conceptual artist and as one of 
the 'Young British Artists', winning the 1997 Turner Prize. In 2007 Wearing was elected as a lifetime member of the Royal Academy of Arts in London (RA).

Evidence of her strong and sustained links with the city of Birmingham is found in her public artworks. In Wearing's Broad Street (2001), she documents the behavior of typical teenagers in British society who go out at night and drink large amounts of alcohol. Wearing shows a collection of photographs entitled 'Broad Street' teenagers partying at various clubs and bars along Broad Street, Birmingham. She follows these teenagers, demonstrating how alcohol contributes to their loss of inhibitions, insecurities, and control. In 2016 her links with the city were strengthened when she received an honorary doctorate from Birmingham City University in recognition of her contribution to the arts. Further public recognition came with the award of the honorary degree of Doctor of Letters, University of London, in 2016.

In many ways, the Ikon Gallery, located in central Birmingham and involved in the coordination of the project, was an ideal partner. It is an independent, exhibition space and one of several flagship institutions in the UK (along with Camden Arts Centre (London), Arnolfini (Bristol), and Modern Art Oxford), for promoting and presenting contemporary and modern art. Founded in 1964, the Gallery developed in the 1970s from a small artist-led space featuring work by founder artists to a high level of engagement nationally. In the following decade, Ikon's programme came under the influence of post-modernism and the increasing popularity of installation. Ikon continued to develop its reputation as a venue for new and innovative work in the 1990s, including sculpture, video, installation and photography, and a community touring programme. In early 1998 the Gallery moved into its current building, Brinley Place. Since 2000 it has moved in a direction that has fostered creative partnerships, becoming both more internationalist and more locally engaged and more committed to its role as a producer. This role encompassed solo projects that offered opportunities for greater in-depth consideration of each artist's work. Such gallery collaborations became the modus operandi for Wearing's family statue projects.

\subsection{The Operationalisation of the Project}

The A Real Birmingham Family project (initially called 'Is your family the face of Birmingham?') was started in 2011/2012, when the city's residents were urged to nominate their families to be the 'face of Birmingham'. Ikon toured different locations across the city and 372 families responded. No limits were placed on how the twenty-first-century family might define itself and nominations included groups of friends, extended families, and people living alone. In 2013 a diverse panel of community, cultural and religious figures chose a shortlist of four-the Clarke family, the Hancox/Treadwell family, the Hay/Wooldridge family, and the Jones family. Discussions on what constitutes a Birmingham family at this time provide a point of access to the kind of family the panel were seeking: 'multiple generations, friendship and diversity as well as evidential links to the city' (Ikon 2014a). The Ikon Gallery added that 'The project draws attention to the unsung, raising questions about civic identity and what constitutes a family today'. It was clearly a more nuanced conception of a family than one that could be derived from statistical measures.

These families that responded formed the core of an exhibition presented in the BBC Birmingham Public Space at The Mailbox in summer 2013. In August 2013, live on BBC Midlands Today, the Jones family, consisting of two local sisters, Roma and Emma, both single mothers, and their two sons, Roma's son Kyan and Emma's son Shaye, was announced as the selected family (Figure 1). Emma is depicted as pregnant with a second son, Isaac, who was born before the sculpture was unveiled. On being announced as the selected family, a unanimous decision, the Jones family commented: 'We feel truly amazed and honoured to be chosen to represent what it means to be a family in Birmingham. We feel it highlights that family is an indestructible bond between people that is universal and it doesn't matter how it is made or what it looks like' (Ikon 2014a). The curator of Ikon, which led the project, highlighted desired family characteristics: ' . . Their story is compelling and says much about contemporary Birmingham: two mixed-race sisters, 
both single-parents with happy, lively young boys, who identify themselves strongly with the city of their birth. The variety of nominations ... has shown to us that whilst the traditional, nuclear family may no longer be the norm, the ties that bind us together are as strong as ever' (Ikon 2013).

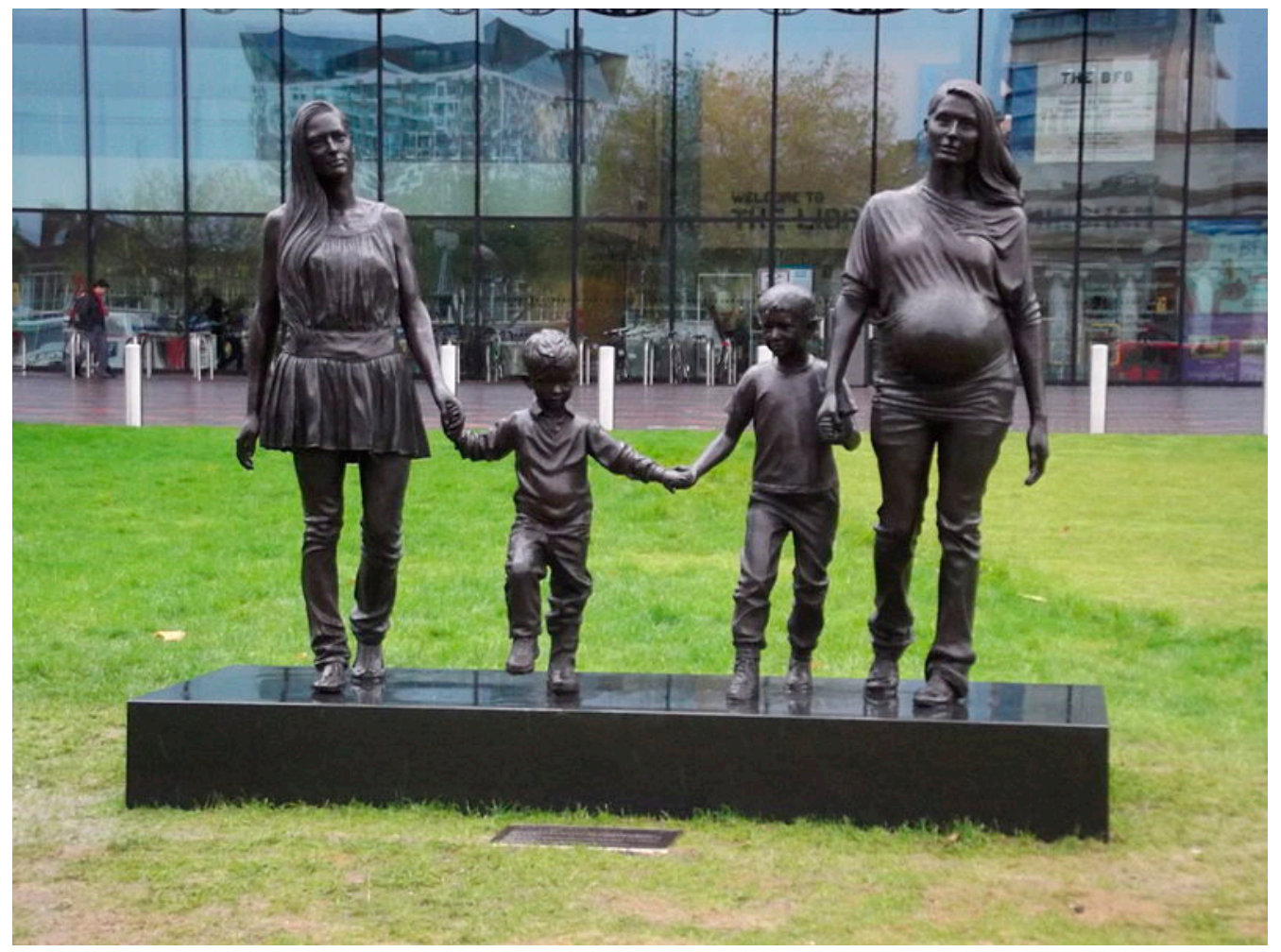

Figure 1. 'A Real Birmingham Family', 2014. Source: https:/ / upload.wikimedia.org/wikipedia/ commons/2/27/Real_Birmingham_Family_statue_-_Library_of_Birmingham_(15119604114).jpg, accessed on 1 May 2021.

The statue was immortalised in bronze, the casting being carried out in China. The four-year project culminated in the statue's unveiling on 30 October 2014 in a prominent position on Centenary Square, outside the new Library of Birmingham, thereby becoming part of the city's public art. The $£ 100,000$ cost of the work was covered by a combination of public money and private donations, including the Arts Council England, Birmingham City Council, and Ikon's Friends of the Family. Subsequently, the statue went into storage in May 2017, to allow work for the redevelopment of Centenary Square to begin. In April 2019 it was relocated in the Square as part of the $£ 15$ million redevelopment of this space.

The sculpture, itself, is a beautifully crafted work (as the Financial Times image of details from the clay models shows (Aspden 2014)). A small plaque laid on the ground in front of the work describes it. Wearing commented: 'I really liked how Roma and Emma Jones spoke of their closeness as sisters and how they supported each other. It seemed a very strong bond, one of friendship and family, and the sculpture puts across that connectedness between them. A nuclear family is one reality but it is one of many and this work celebrates the idea that what constitutes a family should not be fixed (Ikon 2014b)'. The sculpture shows the four family members connected through the holding of hands.

\subsection{Mixed Race Families}

Throughout the age of the modern bureaucratic state, concepts of the 'normal' family have been continuously proposed, frequently ethnocentric in nature and statistically defined. The 'face of Birmingham' project challenges such norms in terms of both ethnic/racial composition and family types. Such issues have a resonance because of the 
family's importance in our identities and everyday lives: 'your family' was identified as the most important of over a dozen identity dimensions by members of all sixteen census ethnic groups (Aspinall and Song 2013). The 'face of Birmingham' project narrows the focus to 'what it means to be a family today', 'the evolving nature of the concept of family', 'the twenty-first-century family', 'multiple generations', 'friendship', 'diversity', 'the unsung', 'the everyday' and 'strength of connection' to the city. With respect to 'diversity', the importance of the dimension of the ethnic/racial composition of the family is underpinned by the fact that three of the four families shortlisted for the 'face of Birmingham' were 'mixed-race' families. Representations of mixing and mixedness are appropriately celebratory, given the long, fraught history of 'mixed-race': they summon the metaphorical isostatic lifting up of a landscape long weighted down. How we measure such diversity in the case of the family has been poorly conceptualised and is infrequently addressed in empirical studies.

While mixed-race families have a long history in Britain (Caballero and Aspinall 2018), it is only since the decennial census in Britain first asked an ethnic group question in 1991 that a robust measure has been available of inter-ethnic unions (marital and cohabiting) (Prior to the 1991 Census some estimates were made using the Labour Force Survey and General Household Survey.). Obtaining a measure of mixed-race families (as opposed to unions) is more complex and is not directly measured by the Office for National Statistics (ONS), although some indicative evidence is available.

The face of a city, as captured by family ethnic/racial diversity, can be assessed on a proxy basis using census measures, if only to give legibility to the symbolism of the representation. These measures show 'mixed-race' families to be a minority in Britain. One proxy is the census measure of multi-ethnic households: two-or-more-person households comprising people from different census ethnic groups living together. In 2011, multi-ethnic households numbered 2 million or $12 \%$, an increase on the 1.4 million in 2001, and a rise in every local authority district bar two (Jivraj and Simpson 2015). However, they could be a mix of, say, 'white Irish' and 'white British' and only half have mixed ethnicity partnerships, around a quarter having different ethnicities only between generations, and the rest, about a fifth, including different ethnicities between unrelated people. The percentage of multiethnic households is highest in Inner London (39\%), falling to 15-27\% in large provincial cities such as Manchester and Birmingham. This proxy clearly overcounts 'mixed-race' families.

Inter-ethnic unions (with/without child(ren)) provide an alternative measure, although not always distinguishing between those inter-ethnic unions with children from those without. With respect to the presence of children, some family types, such as 'blended' 'mixed' families and 'mixed' one-parent families with child(ren), complicate measurement. In 2001, interethnic marriages comprised only $2 \%$ of all marriages (where ethnic background is defined as white, mixed, Asian, black, Chinese or other) (Office for National Statistics 2005). A broader 2001 census measure-comprising both cohabiting and marriedcouple unions across pairs of all sixteen census categories-yields $7 \%$ of all 10.8 million unions in England (Mackintosh 2005). The proportion of people living as part of a couple who were in an inter-ethnic relationship increased from 7 to 9 percent over 2001-11.

A further proxy measure that might seem to have efficacy is the concept of mixed-race households, ONS defining a household as one person living alone, or a group of people (not necessarily related) living at the same address who share cooking facilities and share a living room, sitting room or dining area (ONS defines a family as: A married, civil partnered or cohabiting couple with or without children, or a lone parent with at least one child, who lives at the same address. Children may be dependent or non-dependent. Families are a subset or portion of a household, as more than one family can live in a household.). However, a household can consist of a single family, more than one family, or no families in the case of a group of unrelated people, and is therefore not an accurate measure of the number of families. Moreover, this set of statistics is based on households headed by someone of a particular ethnic group, so 'mixed' ethnicity households are quite different from households where the partnership is an inter-ethnic union. 
Clearly there is no robust measure of 'mixed-race' families, though the foregoing proxies indicate that they are a way off from being the 'statistical' face of modern Britain. However, it is clear that mixed-race families are an example of 'the evolving nature of the concept of family' and are increasingly a 'twenty-first-century family' phenomenon. They represent an important emerging family form that is currently significantly contributing to Britain's growing cultural diversity and will increasingly do so in the future. This is what Wearing sought to convey and not the 'normality' of family form defined by statistics.

While mixedness and its acceptance positioned Wearing's statue as a phenomenon of the new century and an elaboration of the concept of family, it was the combination (or intersection) of family type with race/ethnicity that emphatically cemented this: that is, the sisters were mixed race and also single parents. Attitudes to mixing and mixedness had begun to change in the 1980s and, by the turn of the century, these patterns of family formation were increasingly seen as everyday. Yet mixed-race families have had a long history of subjection to racial prejudice, social bigotry, and moral condemnation (Caballero and Aspinall 2018). In spite of a long presence in the country, they were frequently characterised throughout much of the last century as representative of a moral problem or concern, particularly when headed solely by white mothers (Caballero and Edwards 2010). For example, in Dennis Marsden's study of Mothers Alone (Marsden 1969), 11 of the 116 mothers had dependent children from mixed racial and ethnic backgrounds. These mothers were subjected to prejudice by officialdom, family, and strangers, including the stereotype of resembling prostitutes.

This contrasts with the way the racially/ethnically 'mixed' family has been portrayed as the twenty-first century representative British family, embodying the values of modernity and diversity, the most punchy in this genre being the mixed family portrayed in the 2012 Olympic Games opening ceremony. Similarly, Jessica Ennis was portrayed as 'the face of the Olympics', ' ... of the census', ' ... of a new and evolving Britain'. Wearing's statute is notable for evoking this mood of the new century through the prominence given to mixedness in the initial selection and final choice of a family for the statue. Moreover, its portrayal of mixed-race sisters who are both single parents adds to its interest and noteworthiness, it being the first time that a mixed-race single-parent family has become the focus in public art of a representation of a British family.

\subsection{Social Representations of the Birmingham Statue}

The Birmingham statue, as with much public art, is located in a prominent position in the city, in an area with high pedestrian footfall (39 million a year in the city centre) and close to the landmark Library of Birmingham, Birmingham Repertory Theatre, and the International Convention Centre. This high visibility, art in the public eye, in itself, might be expected to attract public comment and interpretation of the statue. The fact that the statue represents two mixed-race single parents and their children as the 'face of Birmingham' exposes the artwork to criticism from those antagonistic to the conception of a multi-ethnic, multicultural Britain. A number of different representations or interpretations of the artwork have been identified, notably, that it is a 'normal family with no fathers' and that it is not a 'typical family'. How widely such views were held is difficult to ascertain as the local press is likely to have focused on high profile critics. However, blogs at the time of the unveiling of the statue suggest that they reflected discourses amongst a number of commentators. Other 'immediate interpretations' that are difficult to fit into the framework of representations are that the statue appears to portray a lesbian couple ('The Family Portrait': sexuality, gender, ethnicity, class. https:/ / notesoncriticalperspectives.wordpress. com, accessed 1 May 2021.). These interpretations may be set against a representation based on a 'reading' of the artwork and materials associated with its creation.

\subsubsection{Representations: Not a 'Typical Family' and the 'Normal Family with No Fathers'}

These representations originated in comments by two individuals. In the first, shortly after the statue's unveiling in November 2014, New Fathers 4 Justice (a UK-based direct 
action father's rights group campaigning for the rights of fathers to see their children) activist Bobby Smith covered the statue with a white sheet and pictures of his two daughters in protest at no father being included in the statue. Smith commented, 'They've depicted the normal family with no fathers. There's nothing wrong with single mothers but this statue is saying one person can do both jobs, and I believe kids are always better off with both parents in their lives' (emphasis added). Coat-tailing on to his protest, the national The Telegraph (Lyndon 2014) and Daily Mail (Osborne and Dolan 2014) published feature articles supporting Smith's protest (The Guardian and SubScribe, the website for journalists, strongly championed the sculpture). In addition, Birmingham Yardley MP John Hemming commented: 'There's absolutely nothing wrong with single-parent families but I always find it sad when fathers are not involved in the lives of their children'.

Secondly, the right-wing journalist Amanda Platell, the press secretary during 1999_ 2001 to William Hague, then leader of the British Conservative Party, made the clumsy and overstated criticism: 'To claim that they represent a typical family is crass, misleading and deeply cynical' (emphasis added). Such ill-considered comments do not stand alone in Platell's public repertoire: in 2020 the Daily Mail paid damages of $£ 25,000$ to the Cambridge academic Professor Priyamvada Gopal and agreed to pay her legal costs after Platell libellously claimed, citing fake tweets, that she was 'attempting to incite an aggressive and potentially violent race war'.

The language of these two commentators is significant. They refer, respectively, to 'the normal family' and 'a typical family'. Clearly, this is a misrepresentation of the meaning of the statue, as the adjacent plaque quoting Gillian Wearing suggests: 'A nuclear family is one reality but it is one of many and this work celebrates the idea that what constitutes a family should not be fixed'. Neither Wearing nor the Ikon Gallery made any claim that the statue represents either a normal or typical family. The terms 'norm' and 'normal' are frequently used in a statistical context to refer to what is typical or common. However, in the context of the family, it is questionable whether such conceptualisations are easily defined in the early 21st century or are anything more than an abstraction impervious to measurement. These terms, in turn, invoke the contested concept of 'normality' itself.

Ian Hacking (1990, p. 169) has written that the abstract concept of 'normal', albeit somewhat distanced from what it is describing, has nevertheless created a powerful framework for everyday life, including the individual, the family, and social life in general: 'the normal stands indifferently for what is typical, the unenthusiastic objective average, but it also stands for what has been ... and for what shall be, our chosen destiny. This is why the benign and sterile-sounding word 'normal' has become one of the most powerful ideological tools of the twentieth century' (emphasis added). Thus, the concept of the normal was deployed as a mechanism of social control and social regulation, serving the needs of the bureaucratic state by prescriptively connoting the culturally desirable and appropriate.

Hacking's scholarly contributions are part of a wider literature on the concept of normality. Jenkins (1996) describes how collective public discourses, including some public moral campaigns, lead to the identification of deviant social categories which, in turn, 'dramatise and normalise identities and institutions such as the family' (Jenkins 1996, p. 166). He adds: ' . . more routine collective public discourses-for example, the signification of conventional gender roles-dramatise and promote 'normal', positively valorised identities. These are likely to be more ubiquitous themes in advertising, cinema, literature, and so on'. Amongst the facets of the concept of the 'normal' in Hacking's argument, Jenkins highlights the exponential growth of statistics leading to 'a hard image of predictability, legitimated by science and suitable to the needs of bureaucracy' and 'unforgivingly firm models of statistical "normality"'. This included the compilation of statistical distributions in which the mean of the distribution was used to define normality. Theodore Porter (1986) covers some of this same ground in his The Rise of Statistical Thinking. Hand in hand with these developments went the elaboration and invention of modern social categories that invoke 'normality'. 
Other scholars have also elaborated upon the relatively recent statistical concept of 'normality'. Canguilhem ([1943] 1991) has written of the concept of the norm: 'we think that the concepts of norm and average must be considered as two different concepts: it seems vain to try to reduce them to one by wiping out the originality of the first. It seems to us that physiology has better to do than to search for an objective definition of the normal, and that is to recognize the original normative character of life'. He argues that medical conceptions of normality cannot be derived statistically, as qualitative expressions of the pathological or normal involve value judgements.

The idea of a 'normal' or 'typical' family becomes illusory when one looks at the complexity of family types. Families can comprise a multiplicity of members, legal statuses, and different living arrangements. Derivative forms of family type are therefore multiple and complex. The ONS classification of partnership statuses alone, as used on census forms, includes a diversity of types: never married/registered a same-sex civil partnership; married/in a registered same-sex civil partnership; separated, but still legally married/in a same-sex civil partnership; divorced/legally dissolved same-sex civil partnership; and widowed/surviving partner from a same-sex civil partnership. In these different partnerships, there may be biological son/s and/or daughter/s, step-son/s and step-daughter/s, and adopted child/ren. The presence of sons/daughters will create brother or sister relationships, step-brother or step-sister relationships, mother or father relationships, and step-mother or step-father relationships. These partnerships may also include grandchild/ren, grandparent/s, parent/s-in-law, son/s-in-law or daughter/s-in-law, other relations, and unrelated individuals (including foster child/ren).

There may be other axes of differentiation, such as living arrangements and, as already mentioned, the ethnic composition of the family. While most families, especially those with dependent children, are likely to be living in the same physical space (that is, a household), this is not always the case. The ONS identified 'living apart together' families: in 2011 640,000 of the married population were not living together as a married couple, though they said that they were married or civil partnered, not separated, but not living in a couple (Office for National Statistics 2014a). As noted, families that comprise inter-ethnic unions are becoming more common. Nearly 1 in 10 people ( $9 \%$ or 2.3 million) who were living as part of a couple were in an inter-ethnic relationship in England and Wales in 2011. This may undercount or exclude other family types, such as 'blended' 'mixed' families and 'mixed' one-parent families with child(ren). Some $7 \%$ of dependent children lived in a household with an inter-ethnic relationship (Office for National Statistics 2014b).

Sociologists and anthropologists have attempted to derive from these complex patterns of membership and living arrangements distinct 'family forms' or forms of family diversity. Some of these typologies or family classifications are inordinately long and lack utility. Nevertheless, some usefully identify readily recognizable discrete family categories, such as the 'nuclear family' (now probably of diminished utility), the 'extended family', the 'joint family', and the 'blended family'. Joint families are composed of sets of siblings and their dependent children, with or without their spouses, a family form that fits the Joneses and their statue, though the sisters live separately. Other types that have been distinguished include 'matrifocal lone parent families' and 'patrifocal lone parent families', and, as noted in the UK, 'living apart together' families. Some families may belong to more than one form or category.

For much of the last century, the 'nuclear family' was regarded as the norm. This family form was used to refer to a unit consisting of opposite-sex spouses and their dependent child/ren. However, Scott and Marshall (2005, p. 212) observe: 'What is clear is that, with rising divorce rates and the ageing of the population, the nuclear family is no longer the norm in either Britain or America'. There is little data on the current prevalence of these family forms so it is difficult to establish their representativeness. However, it is clear that there is now a plurality of family types with no one type dominating or meriting the title of 'normal'. The Labour Force Survey (LFS) provides a typology of families by family type on an annual basis, but this excludes such categories as extended 
family, joint family, and blended family. Table 1 shows that of the total of 46,285,000 people in families, the largest in these terms was 'married couple family with dependent children' $(36.8 \%)$ (a standard definition of the nuclear family (Oxford Languages: https: / /languages.oup.com/google-dictionary-en/, accessed 1 May 2021)), followed by 'married couple family with no children' $(22.3 \%)$, and lone parent family $(13.5 \%)$.

Table 1. Families by family type and presence of children, England, 2019.

\begin{tabular}{|c|c|c|}
\hline \multicolumn{3}{|c|}{ Number of People in Families (Thousands), 2019} \\
\hline & Estimate & $C I+I-$ \\
\hline Married couple family & 31,733 & 331 \\
\hline No children & 10,323 & 195 \\
\hline Dependent children & 17,015 & 278 \\
\hline Non-dependent children only & 4394 & 193 \\
\hline Civil partner couple family & 80 & 22 \\
\hline No children or non-dependent children only & 65 & 20 \\
\hline Dependent children & 15 & 11 \\
\hline Opposite sex cohabiting couple family & 8037 & 248 \\
\hline No children & 3301 & 136 \\
\hline Dependent children & 4226 & 201 \\
\hline Non-dependent children only & 511 & 75 \\
\hline Same sex cohabiting couple family & 192 & 41 \\
\hline No children or non-dependent children only & 189 & 41 \\
\hline Dependent children & 3 & 4 \\
\hline Lone parent family & 6244 & 206 \\
\hline Dependent children & 4276 & 169 \\
\hline Non-dependent children only & 1967 & 118 \\
\hline Lone mother family & 5423 & 188 \\
\hline Dependent children & 3884 & 161 \\
\hline Non-dependent children only & 1539 & 103 \\
\hline Lone father family & 820 & 81 \\
\hline Dependent children & 392 & 59 \\
\hline Non-dependent children only & 429 & 57 \\
\hline All families & 46,285 & 201 \\
\hline No children & 13,878 & 222 \\
\hline Dependent children & 25,535 & 152 \\
\hline Non-dependent children only & 6872 & 213 \\
\hline
\end{tabular}

Source: ONS. Labour Force Survey.

'Normality', as exemplified here by the 'nuclear family', is clearly a statistical construction of modern government. Writing in the late 1990s, Collins (1998) said of this family form: 'Defined as a natural or biological arrangement based on heterosexual attraction, this monolithic family type articulates with governmental structures. It is organized not around a biological core, but a state-sanctioned, heterosexual marriage that confers legitimacy not only on the family structure itself but on children born into it'. There is, however, another way of understanding normality outside the constraints of this artefact. Hacking (1990) writes of 'the imprecise everyday probability of chance and experience'. In a similar vein Jenkins (2008, p. 9) inveighs against the attempts 'to impose theoretical order on a human world in which indeterminacy, ambiguity and paradox are part of the normal pattern of everyday life' (emphasis added). Such imprecision and indeterminacy characterises the way members of the wider society come together in unions and other forms of connectedness and this has been the case in the past. For example, government surveillance of families in provincial cities in the 1960s found marital and cohabiting unions, lone-parent families, and diversity in ethnic/racial terms (Caballero and Aspinall 2018). This normal pattern of everyday life frames the social representation of a real Birmingham family developed here. 
2.4.2. Social Representations of a Real Birmingham Family: Wearing's Destabilization of the Meaning of the Family

It is evident from the Ikon Gallery and Gillian Wearing's comments that the meaning of the sculpture is nuanced and located in the complex terrain of diverse family forms. The statue is of a 'joint family' comprising two 'matrifocal lone parents' and their children. Gillian Wearing emphasises the importance of closeness, support, connectedness, and the strength of the bond within families. She argues that how the family is defined should not be fixed as there are many possible realities, the nuclear family being but one. The sculpture embodies and celebrates these qualities of connectedness and fluidity of forms that the family can take. Similarly, Stuart Tulloch, curator at Ikon, claimed that the variety of nominations for the statue demonstrated that the traditional, nuclear family may no longer be the norm and emphasised the importance of strength of ties within the family.

Wearing opens up the idea of the family in new ways rather than simply providing pointers to what the family can comprise with respect to less well-known forms. She transforms the meaning of the family and destabilizes it in several significant ways. By focusing on the 'real family', she is objectifying the family in terms of what happens in the real world, as opposed to the common visual stereotypes of the media and other commentators. The importance of closeness, support, and connectedness raises the possibility of new configurations of the family brought into existence by the particularities of a group of socially connected persons who so nominate themselves. The power to define the family thereby shifts from demographers and sociologists to those in relationships who collectively identify in this way.

Thus, the family is defined empirically, experientially, and first-hand. Arguing that the definition should not be fixed, Wearing invites us to conceptualise the family in novel ways. Indeed, the press release for 'a real Birmingham family' stated: 'Thousands of families are expected to nominate themselves, but rather than choosing the statistically average family, there will be a comparison of value judgments about authenticity, locality and what it is that essentially constitutes a family. Issues arising out of sexual politics (e.g., gay parenting), fostering, cultural diversity (embracing notions of the extended family), surrogacy and countless variations on the theme of marriage will be taken into consideration'. The nominations in the selection process included groups of friends, extended families, and people living alone. The family does not have to be a group of related people, as dictionary definitions suggest. Nor does it need to be a co-resident unit: the Jones' sisters and their children did not live in the same household.

Families empirically defined are likely to be diverse in multiple ways, including their ethnic/racial composition. The Birmingham family comprises mixed-race sisters and the partners in the selected Italian and Danish families are of different national origins. This is clearly a pattern that has come about with increased transnational migration, border crossing, and population mixing. While the 'nuclear family' is referenced and may be said to be represented in two of the three statues, this seems to take a secondary place when the context of transnational patterns of mobility and family formation are considered. The idea of place-based identities is also challenged in these statues: links to the city were important in the case of the Birmingham family, though the importance of local belonging is set against the mobility trajectories of the Italian and Danish families.

This representation clearly situates the interpretation of the statue in the postmodern twenty-first century, usually defined in terms of differences without hierarchy and invoking the complexity and diversity of meanings, subjectivism, an emphasis on pluralism, and a general distrust of theories. With a focus on the dynamic and fragmented nature of individual identities, the stable notion of the norm does not have a clear place. In harmony with postmodernism, it exposes the hegemonic narrative of normality and the nuclear family, which has masked or submerged the diversity in forms of the family that has always existed in the past (illustrated in this paper by mixed-race and lone-parent families). The artwork opens the way for that diversity to exist in the twentieth-first century: representing just one of many possible family types, it provocatively reveals a mixed-race family of 
single parents, so long vilified in Britain's past. Further, by transforming the meaning of the family by locating its definition in 'real families', the idea of what constitutes a family is democratised and liberated from traditional definitions and hierarchical typologies.

The rationale for the $A$ Real Birmingham Family statue was different from that for Gillian Wearing's bronze statue representing 'A Typical Trentino Family' in 2007-08 (Figure 2), although the concept for the Birmingham statue appears to have developed out of her Italian project. In A Typical Trentino Family, curated by Fabio Cavallucci and Cristina Natalicchio, a local family-the Giulianis-was selected by a panel to be immortalised in a bronze sculpture. During the process the artist worked with statisticians led by Ivano Bison, Professor of Methodology and Statistics at the Faculty of Sociology of Trento, who gave her the breakdown of what the typical family in Trento consisted of, taking into account the type of family, number of family members, age, job, lifestyle, and assets. Their definitions of a family were surprisingly wide-ranging and included one person living alone. Thus, while the Trentino family conforms with the nuclear family, an opposite-sex couple with two dependent children, it was the range of family types identified in establishing the 'norm' that impressed itself upon Wearing, who found this diversity an inclusive way of regarding family and applied it to the search in Birmingham. Moreover, in the statue of the nuclear family of the Giulianis, the union comprised a Greek wife and Italian husband, challenging - as did the Birmingham statue-the stereotype of ethnic/national homogeneity in the family.

The selection process for Gillian Wearing's statue of 'A Real Danish Family' was somewhat different from the process for the Trento statue and has substantial commonality with the Birmingham project. Wearing set out to find a real Danish family to be depicted as a life-sized bronze sculpture located in central Copenhagen, supported by the Bikuben Foundation, the City of Copenhagen, and the Danish Arts Foundation. The project was launched in autumn 2016 through a campaign inviting all families in Denmark to take part in the competition. 492 families representing a range of family types from 14 different cities across the country participated (a third more than for the Birmingham statue but in the context of national capture). The Danish broadcasting corporation, DR, followed the entire selection process, from interviews with these participating families to the panel's deliberations and the final choice of family, as documented in its three TV programmes about the project in October 2017. The nationwide project was a collaboration between Gillian Wearing, Kunsthal Aarhus, DR and the National Gallery of Denmark (SMK), celebrating the many different types of family found in Denmark. The chosen family and the sculpture were revealed on 13 October 2017 at SMK, at the time of the opening of the exhibition 'Gillian Wearing-Family Stories'.

A Real Danish Family shows Michael Lysholm Thorsen, a 29-year-old man with Danish parentage but born in Italy, Yenny-Louise, a 28 -year-old woman born in Colombia but raised in Denmark with adoptive parents, and their baby daughter (Figure 3). As with the Birmingham statue, the Danish statue depicts a 'mixed' family. While the family may be said to be 'nuclear' in form, this appears to be subsidiary to the complex histories of the partners. The focus is on the uniqueness of the family and its symbolic representation of contemporary Denmark, questioning whether family forms located outside traditional norms are equally regarded. 


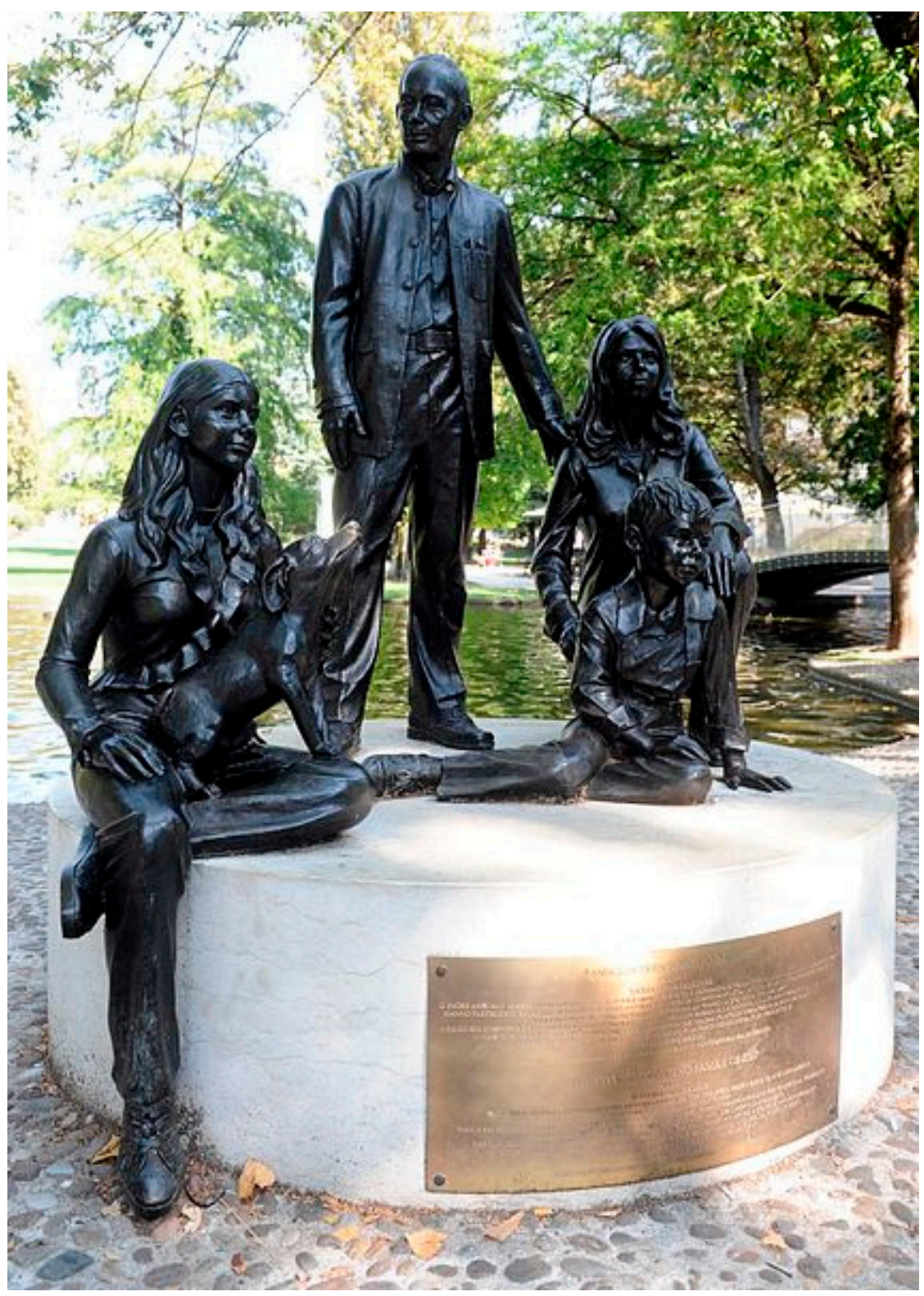

Figure 2. 'A Typical Trentino Family', 2008. Source: This image is credited to: Niccolò Caranti (own work, date 28 September 2016): the file is licensed under the Creative Commons AttributionShare Alike 4.0 International license. (https: / / commons.wikimedia.org/wiki/File:Monumento_alla_ Famiglia_Trentina_(Trento)_02.jpg), accessed on 1 May 2021.

Wearing's exhibition at the SMK, 'Family Stories', was a collaboration between the artist, the museum's designers, and RBS Studio: 'It takes visitors from a darkly-lit space, displaying Wearing's most famous works from 1992 to the present day, to a noticeably smaller, white-washed room explaining the making of A Real Danish Family. This shift not only serves as a literal representation of important topics that were previously left in the dark and are now being brought to light, but also encourages an open and honest discussion' (Hametner 2017).

Wearing does not claim that the A Real Danish Family statue represents a normal, typical, or ideal family form for these times but, as in the case of the Birmingham statue, emphasises the diversity of family types, their strengths, endurance as social units, and their realness and uniqueness. 


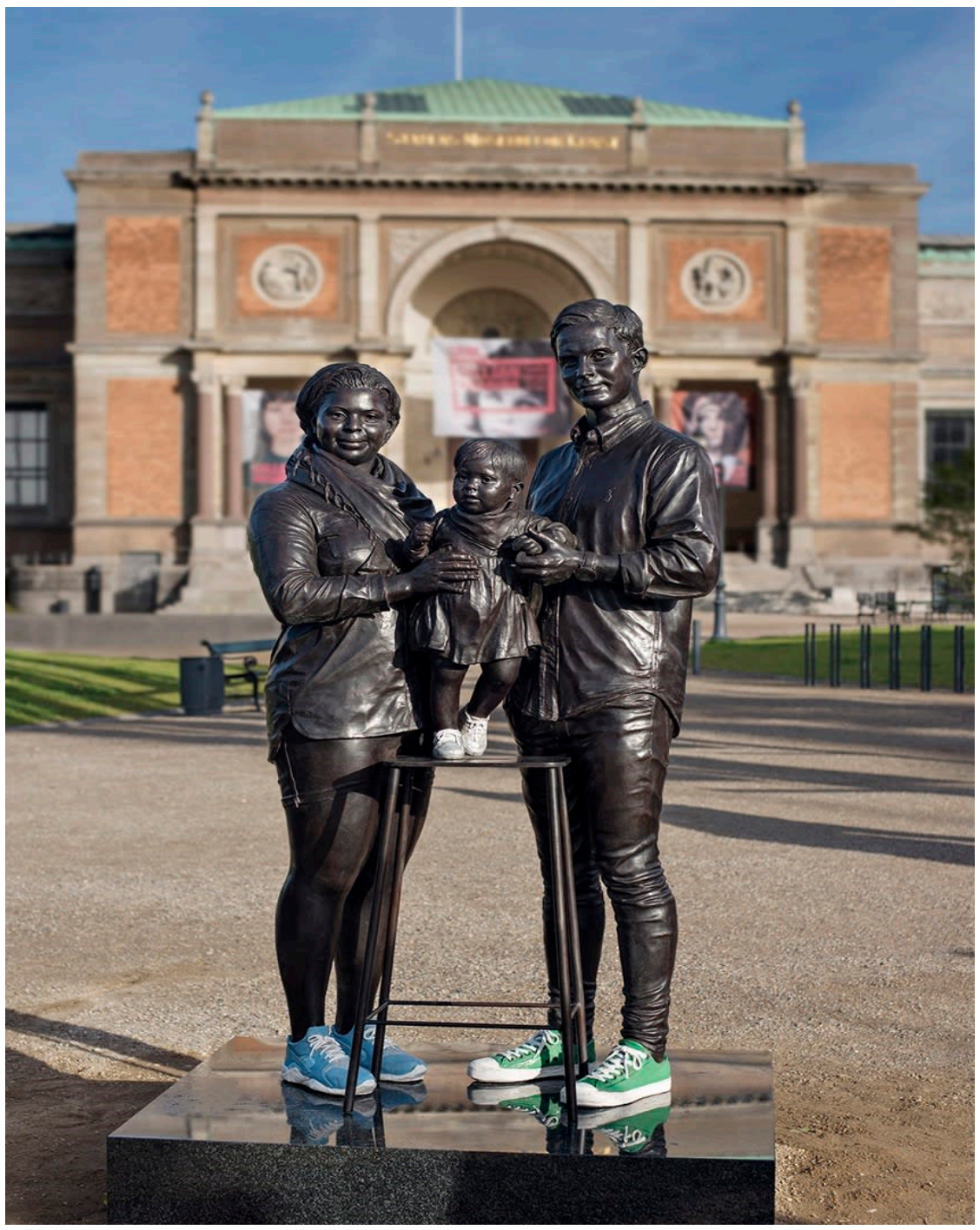

Figure 3. 'A Real Danish Family', 2017. Source: https:/ /www.tanyabonakdargallery.com/artists / 64 -gillian-wearing/works/10301-gillian-wearing-a-real-danish-family-2017/. Photograph credited to Heine Pedersen. Accessed on 1 May 2021.

\section{Discussion}

Social or cultural representation offers a reconstruction of the original source that is represented, that is, what it seems to be or means to the person who represents it. Such meaning contributes to or shapes wider social understandings. In some circumstances, representations may, through the repeated re-creation and endorsement of ideas, give rise to stereotypes relating to such matters as gender and the family. The understanding of such representations requires an investigation of who constructed the meaning and the 'where' and 'when' of this process, the purpose that lies behind the representation, and the intended audience.

This study of 'A Real Birmingham Family' has shown how public art can be interpreted in diverse ways by the media, commentators and the public that differ from representations that draw upon but extend the interpretations of the creator of the artwork and its curators. It is important that we question these different representations as such images can assume power and authority and disguise or silence the reality of the work.

The representations of the statue using the criteria of the 'typical family' and the 'normal family with no fathers' fail in their task to present to the public a meaningful interpretation of the artwork. Both are ideological representations that are value-laden, 
purposive, and encumbered with bias. They are a response to a visual experience, where the visual merely constitutes the object of analysis (Chaplin 1994), ignoring the meaning accorded to the artwork by Gillian Wearing and the Ikon Gallery and statements relating to this on the statue's plaque. Meaning is only constructed using the commentators' own set of ideologies and values. Several national newspapers are seen to be active in privileging these viewpoints which are consistent with their political orientations and constructed with a particular audience in mind. Moreover, the heavy use of images depicting onlookers in the Daily Mail's piece seeks to turn the unveiling of the statue into a social spectacle.

It is clear that representations frequently invoke particular agendas and may conflict with other competing representations. If we dissociate our understanding of 'normality' from the constraints of the artefactual nuclear family and define it in terms of ambiguity, imprecision, and indeterminacy, then the 'real Birmingham family' can be framed as destabilizing current meanings of the family. By focusing on the 'real family', Wearing is objectifying the family in terms of what happens in the real world. New configurations of the family are brought into existence by the particularities of a group of socially connected persons who so nominate themselves. The power to define the family thereby shifts from demographers and sociologists to those in relationships who collectively identify in this way. It is, by definition, an inclusive approach, that contrasts with the 'nuclear family' created as a distinctive category by excluding or submerging other family types that do not fit this construction. With a turn to the experiential, Wearing highlights a specific type of family brought to our attention by the Jones sisters who nominate their 'joint family'. She thereby overhauls our vocabulary for the family, defining it by what members in the wider society choose to self-identify as 'family', and championing the 'unsung', 'ordinary lives', and the unrecognised amongst family types. That position has evolved through a previous project in Italy and is sustained in a further Danish project, both highlighting ethnic/national diversity in the family. While the Italian statue deliberately depicts a 'statistically average' family but exposing the true range of family types in the selection process, the Danish family is 'nuclear' in type only nominally and incidentally, the representation focusing on the diverse origins of the partners.

The sustainability of representations may depend on many factors, including their relationship with their real-world subjects and the effectiveness of the media in framing such representations. If the media succeeds in repeatedly presenting representations of images and texts, such representations may assume the quality of 'naturalness' and disrupt the real-world meaning of these images and objects. In the case of the Birmingham statue, the critiques of the artwork were made at the time of its unveiling and in a predictable and unthinking way, without consideration of the wider context, the frame of reference that informed the statue's creation. The involvement of the media turned out to be transitory and their representations and those of the commentators did not 'stick'. A more penetrating interpretation of the artwork is offered, that is in tune with the provocative nature of Wearing's artwork.

\section{Materials and Methods}

Structured searches were undertaken on databases of abstracts of literature-including Oxford Art Online, SocINDEX, Zetoc, and Google Scholar-and on citation databases of peerreviewed literature-ISI Web of Knowledge, including Arts and Humanities Citation Indexand SCOPUS. Search terms used, both as stand-alone words/phrases and in Boolean search algorithms, were 'Gillian Wearing', 'Ikon Gallery', 'A Real Birmingham Family', 'the Face of Birmingham', 'a typical Trentino family', 'a real Danish family', 'social representation', and 'cultural representation'. The full text was retrieved of all relevant papers. The website of the Office for National Statistics was also searched for documents on inter-ethnic unions, multi-ethnic households, and family and household types and their prevalence in the UK.

Photographs of Gillian Wearing's statues of families in Birmingham, Trento/Trentino, and Copenhagen were identified on Google Images. Use was also made of the University of Kent's Templeman Library digital newspaper archive collections. 
The study uses the method of narrative review to evaluate the different representations of the statue of 'A Real Birmingham Family'.

Funding: This research received no external funding.

Institutional Review Board Statement: Not applicable.

Informed Consent Statement: Not applicable.

Data Availability Statement: Not relevant.

Acknowledgments: The author is grateful to the two anonymous peer reviewers for their informative comments.

Conflicts of Interest: The author declares no conflict of interest.

\section{References}

Aspden, Peter. 2014. Statue of a family: By Gillian Wearing. Gillian Wearing. Financial Times. July 18. Available online: https: / / www.ft.com/content/171e7030-0d3c-11e4-bcb2-00144feabdc0 (accessed on 1 May 2021).

Aspinall, Peter. 2015. Social representations of 'mixed-race' in early twenty-first-century Britain: Content, limitations, and counternarratives. Ethnic and Racial Studies 38: 1067-83. [CrossRef]

Aspinall, Peter, and Miri Song. 2013. Is race a 'salient' or 'dominant identity' in the early 21st century. The evidence of UK survey data on respondents' sense of who they are. Social Science Research 42: 547-61. [CrossRef] [PubMed]

Caballero, Chamion, and Peter Aspinall. 2018. Mixed Race Britain in The Twentieth Century. London: Palgrave Macmillan.

Caballero, Chamion, and Rosalind Edwards. 2010. Lone Mothers of Mixed Racial and Ethnic Children: Then and Now. London: Runnymede.

Canguilhem, Georges. 1991. The Normal and the Pathological. New York: Zone Books, [Translated by Carolyn R. Fawcett and Robert S. Cohen. Originally published as a collection of papers in 1943 with the title Essai sur quelques problemes concernant le normal et le pathologique]. First published 1943.

Chaplin, Elizabeth. 1994. Sociology and Visual Representation. London: Routledge.

Collins, Patricia Hill. 1998. It's All in the Family: Intersections of Gender, Race, and Nation. Hypatia 13: 62-82. [CrossRef]

Hacking, Ian. 1990. The Taming of Chance. Cambridge: Cambridge University Press.

Hall, Stuart. 1997. The work of representation. In Representation: Cultural Representations and Signifying Practices. Edited by Stuart Hall. London: Sage Publications Inc.

Hametner, Jessica Christin. 2017. Gillian Wearing keeps it in the family at Copenhagen's National Gallery. October 27. Available online: https:/ / www.wallpaper.com/art/gillian-wearing-family-stories-national-gallery-of-denmark (accessed on 1 May 2021).

Ikon. 2013. The Jones Family Named 'A Real Birmingham Family'. August 27. Available online: https://ikon-gallery.org/wp-content/ uploads /2013/10/Gillian-Wearing-chosen-family-PR-FINAL.pdf (accessed on 1 May 2021).

Ikon. 2014a. A Real Birmingham Family. Available online: https://www.ikon-gallery.org/event/a-real-birmingham-family-9/ (accessed on 1 May 2021).

Ikon. 2014b. A Real Birmingham Family_Launch Event. Available online: https://www.ikon-gallery.org/event/a-real-birminghamfamily-launch-event/ (accessed on 1 May 2021).

Jenkins, Richard. 1996. Social Identity. London and New York: Routledge.

Jenkins, Richard. 2008. Social Identity, 3rd ed. London and New York: Routledge.

Jivraj, Stephen, and Ludi Simpson. 2015. 'How has ethnic diversity grown?'. In Ethnic Identity and Inequalities in Britain. Edited by Stephen Jivraj and Ludi Simpson. Bristol: Policy Press, pp. 19-31.

Lorenzi-Cioldi, Fabio, and Alain Clémence. 2010. 'Social Representations'. In Encyclopedia of Group Processes and Intergroup Relations. Edited by John M. Levine and Michael Hogg. London: Sage, pp. 823-25.

Lyndon, Neil. 2014. Is Gillian Wearing's family sculpture offensive to fathers? The Telegraph, November 3.

Mackintosh, Marion. 2005. Inter-Ethnic Unions. DMAG Update 2005/12. London: GLA.

Marsden, Dennis. 1969. Mothers Alone: Poverty and the Fatherless Family. London: Allen Lane.

Moscovici, Serge. 1963. Attitudes and opinions. Annual Review of Psychology 14: 231-60. [CrossRef] [PubMed]

Muscovici, Serge. 1961. La Psychanalyse, son Image et Son Public. Paris: Presses Universitaires de France.

Office for National Statistics. 2005. Focus on Ethnicity E Identity ('Inter-ethnic marriages'). London: ONS.

Office for National Statistics. 2014a. How Have Living Arrangements and Marital Status in England and Wales Changed Since 2001? London: ONS. Available online: file:/ / C:/Users/Peter/Downloads/How\%20Have\%20Living\%20Arrangements\%20and\%20Marital\% 20Status\%20in\%20England\%20and\%20Wales\%20Changed\%20Since\%202001_.pdf (accessed on 1 May 2021).

Office for National Statistics. 2014b. 2011 Census analysis: What does the 2011Census Tell Us about Inter-Ethnic Relationships? London: ONS. Available online: file:/ / C:/Users/Peter/Downloads/2011\%20Census\%20analysis\%20What\%20does\%20the\%202011\%2 0Census\%20tell\%20us\%20about\%20Inter-ethnic\%20Relationships_.pdf (accessed on 1 May 2021).

Olusoga, David. 2020. I wanted to join protesters who tore down Colston statue. The Guardian Tues, September 1. 
Osborne, L., and A. Dolan. 2014. Two single mums (one pregnant), their children- and not a dad in sight. Birmingham's $£ 100 \mathrm{k}$ vision of the modern British family! Daily Mail, October 31.

Porter, Theodore M. 1986. The Rise of Statistical Thinking 1820-1900. Princeton: Princeton University Press.

Scott, John, and Gordon G. Marshall. 2005. Oxford Dictionary of Sociology. Oxford: Oxford University Press. 